\title{
Las w ujęciu systemowym. Słabe i mocne strony
}

\author{
Grzegorz Embros \\ Instytut Ekologii i Bioetyki, Wydział Filozofii Chrześcijańskiej \\ Uniwersytet Kardynała Stefana Wyszyńskiego w Warszawie, ul. Wóycickiego 1/3, 01-938 Warszawa \\ g.embros@uksw.edu.pl
}

\section{Streszczenie}

W artykule przedstawiono przykładowe metody opisu zagadnień objętych zarówno systemem „leśnym", jak i jego podsystemami. Ma to na celu doprecyzowanie sposobu budowania systemowego obrazu lasu i jego podsystemów. Zestawione będą mocne i słabe strony takiego ujęcia oraz możliwości ich uwzględnienia w profilowaniu relacji człowiek - las. Zwrócona będzie uwaga na poszerzanie interpretacji ujęcia systemowego i wynikające z tego konsekwencje. Powyższe, wraz z analizą konsekwencji, stanowi centralny punkt i zasadniczy cel artykułu. Tak zarysowana perspektywa systemowa może być spożytkowana, na przykład, w edukacji środowiskowej. W jej ramach, może wspomagać opis czy objaśnianie mechanizmów lub zjawisk występujących w ramach systemu "las". Poza tym, może stanowić podstawę, w oparciu o którą będą wypracowane „narzędzia systemowe", wykorzystywane następnie przy kształtowaniu postaw i działań człowieka względem lasu, będzie się przekładać na stan relacji pomiędzy człowiekiem a lasem. Może to znaleźć odzwierciedlenie w, szeroko rozumianym, procesie decyzyjnym poprzedzającym działania podejmowane w zakresie gospodarowania przez człowieka systemem leśnym.

\section{Słowa kluczowe}

las, ujęcie systemowe, antropomorfizacja, interpretacja

\section{Wstęp}

Lektura książki Petera Wohlleben'a Sekretne życie drzew, wzbudza zainteresowanie dzięki warstwie treściowej, ale również inspiruje, do podjęcia zagadnienia wyznaczonego tytułem artykułu, dzięki sposobowi ujmowania i opisowi treści merytorycznych. Proponowane tam systemowe ujęcie prezentowanych zagadnień, staje się punktem wyjścia do „rozszerzania analogii” i personifikacji podsystemów systemu „las”. Takie sprofilowanie narracji, przekłada się na sposób opowiadania o mechanizmach, relacjach, oddziaływaniach itp. opisywanych systemów, co w konsekwencji skutkuje wykreowaniem określonego obrazu lasu - jako "superorganizmu".

W artykule zostaną zaprezentowane przykładowe sposoby opisu problematyki podejmowanej w książce - zarówno, gdy chodzi o podsystemy systemu "las”, jak i system „las”. Uszczegółowione będą zagadnienia związane z ujęciem systemowym (Por. Weinberg 1979; Gomółka 1994; Laszlo 1978). Ma to na celu doprecyzowanie sposobu budowania systemowego obrazu lasu i jego podsystemów. Zestawione będą mocne i słabe strony takiego ujęcia oraz możliwości ich 
uwzględnienia w profilowaniu relacji człowiek - las. Zwrócona będzie uwaga na poszerzanie interpretacji ujęcia systemowego i wynikające z tego konsekwencje.

Powyższe, wraz z analizą konsekwencji, stanowi centralny punkt i zasadniczy cel artykułu. Tak zarysowana perspektywa systemowa może być spożytkowana, na przykład, w edukacji środowiskowej. W jej ramach, może wspomagać opis czy objaśnianie mechanizmów lub zjawisk występujących w ramach systemu "las". Poza tym, może stanowić podstawę, w oparciu o którą będą wypracowane "narzędzia systemowe”, wykorzystywane następnie przy kształtowaniu postaw i działań człowieka względem lasu, będzie się przekładać na stan relacji pomiędzy człowiekiem a lasem. Może to znaleźć odzwierciedlenie w, szeroko rozumianym, procesie decyzyjnym poprzedzającym działania podejmowane w zakresie gospodarowania przez człowieka systemem leśnym. Tym bardziej istotne jest, aby systemowe ujęcie było w tym przypadku wolne od błędów.

\section{Systemowe ujęcie lasu Wohllebena}

Systemowa perspektywa zastosowana przez autora książki Sekretne życie drzew nie odbiega od innych tego typu zabiegów narracyjnych stosowanych zarówno w literaturze popularnej, popularno-naukowej a niekiedy także i naukowej ${ }^{1}$. W opracowaniach korzystających z takiego sposobu podejmowania treści merytorycznych, można zidentyfikować zestaw określonych zagadnień. Należą do nich: relacje system - otoczenie, odniesienia do struktury systemów, do ich wła-

1 Można tu wymienić chociażby: Laszlo, Ervin (1978): Systemowy obraz świata; Lorenz, Konrad (1977): Odwrotna strona zwierciadta; Lovelock, James (2003): Gaja. Nowe spojrzenie na życie na Ziemi; Ward, Peter (2010): Hipoteza Medei; Schrödinger, Erwin (1998): Czym jest życie? Fizyczne aspekty żywej komórki; Zięba, Stanisław (2013): Życie. Koncepcja emergentystyczna; Scruton, Roger (2017): Zielona filozofia; Dorst, Jean (1987): Siła życia; Dubos, Rene (1986): Pochwała różnorodności; Bateson, Gregory (1996): Umyst i przyroda itd. sności (sprzężenia, adaptacja, stabilność, homeostaza) czy funkcji (informowanie, łączność, transport, sterowanie), a także do hierarchii systemowej (system wielki i jego podsystemy) (Por. Mynarski 1979; Lubański 1992: 13-153). W niniejszym artykule rozważanym, szczególnym przypadkiem systemu jest las. Tym samym, systemowe ujęcie lasu proponowane przez Wohlleben'a wydaje się odpowiednim przykładem, w odniesieniu, do którego możliwe jest prowadzenie dalszych rozważań. W najbardziej ogólnej perspektywie, las prezentuje się jako system wielki (las jako superorganizm). Nie są pomijane również podsystemy systemu wielkiego - rośliny (ze szczególnym uwzględnieniem drzew) czy zwierzęta. W odniesieniu do takiego konstruktu, mogą być prowadzone rozważania w duchu ujęcia systemowego.

\section{Systemowe funkcje i własności lasu}

Ujmowanie lasu jako systemu wielkiego powoduje, że „[w] istocie mamy do czynienia z zawikłanym systemem, który łączy większość osobników jednego gatunku w drzewostanie. Wymiana składników pokarmowych - sąsiedzka pomoc w razie potrzeby - jest widocznie regułą, co prowadzi do stwierdzenia, że lasy stanowią superorganizmy, czyli są podobnymi tworami jak na przykład mrowiska." (Wohlleben 2016: 12-13). Dzięki takiej perspektywie możliwe staje się określenie struktury i relacji występujących pomiędzy wchodzącymi w grę systemami. Ponadto, możliwe stają się analizy odwołujące się do własności i funkcji systemów. Wśród funkcji, ważne miejsce zajmuje informowanie i komunikacja. W systemie leśnym mogą być one realizowane za pomocą zapachów, drogą wizualną a także foniczną. W relacjach pomiędzy systemami leśnymi „[k]luczowe znaczenie ma współpraca na wczesnym etapie ostrzegania. Tu jednak drzewa polegają nie tylko na drodze powietrznej, bo wtedy przecież nie wszyscy sąsiedzi zwietrzyliby niebezpieczeństwo. Wolą raczej wysyłać wiadomości także przez korzenie, które łączą w sieć 
wszystkie osobniki i działają niezależnie od pogody. Co zaskakujące, wiadomości są przekazywane nie tylko chemicznie, ale nawet elektrycznie, i to z prędkością centymetra na sekundę." (Wohlleben 2016: 19). Komunikacja foniczna również może mieć miejsce: „[a]paratury pomiarowe zarejestrowały ciche trzaski korzeni przy częstotliwości dwustu dwudziestu herców. Trzeszczące korzenie? To jeszcze nie musi nic znaczyć, w końcu nawet martwe drewno trzeszczy najpóźniej w momencie, w którym pali się $\mathrm{w}$ piecu. Jednak stwierdzone w laboratorium odgłosy były słyszane nie tylko przez badaczy. Reagowały na nie korzenie postronnych siewek. Zawsze, gdy wystawiano je na trzaski o częstotliwości dwustu dwudziestu herców, ich wierzchołki kierowały się w tę stronę. Oznacza to, że trawa może rejestrować, powiedzmy śmiało - „słyszeć”, tę częstotliwość. Wymiana informacji za pomocą fal dźwiękowych u roślin? Budzi to ciekawość, bo przecież i my, ludzie, jesteśmy przysposobieni do komunikacji dźwiękowej i może to byłby klucz do lepszego zrozumienia drzew." (Wohlleben 2016: 22-23). System leśny realizuje funkcje komunikacyjne także na znacznie wyższym poziomie „[w] celu zagwarantowania szybkiego rozchodzenia się wiadomości w sprawę z reguły włączane są grzyby. Działają one jak światłowodowe łącza Internetu. [...] Jeden tylko okaz jest w stanie w ciągu stuleci rozprzestrzenić się na powierzchni kilku kilometrów kwadratowych i w ten sposób opleść siatką całe lasy. Swoimi nitkami przekazuje sygnały od jednego drzewa do drugiego i pomaga im $\mathrm{w}$ wymianie wiadomości o owadach, suszach czy innych niebezpieczeństwach. Dziś już nawet nauka mówi o „Wood-Wide-Web”, która oplata nasze lasy. [...] Bardzo możliwe, że również rozmaite gatunki drzew kontaktują się między sobą, nawet jeśli traktują się jak konkurencję. Grzyby zaś realizują własną strategię, a ta może być bardzo mediacyjna i ugodowa." (Wohlleben 2016: 20-21). Opisana funkcja komunikacyjna może być realizowana dzięki własności systemów, jaką jest wchodzenie $w$ interakcje poprzez tworzenie sprzężeń - w tym przypadku sprzężeń realizowanych $w$ ramach kooperacji z grzybami.

Kolejną funkcją realizowaną przez leśne systemy jest transport. Autor Sekretnego życia drzew poświęcił jeden z rozdziałów (por. rozdział Na północ: 191-199) właśnie tej funkcji. Opisane są tam sposoby wielopokoleniowego przemieszczania się lasów z południa na północ globu. Przemieszczanie, o którym tu mowa wiąże się ściśle z transportem wody i pyłku czy nasion. Przemieszczanie to, odbywa się w obrębie całego wielkiego systemu leśnego, wraz z jego podsystemami. W opowieści Wohlleben'a, chociaż na pierwszym planie są drzewa, to znakomicie przedstawiona jest kooperacja w ramach wzajemnych oddziaływań wszystkich, wchodzących w grę, systemów. Kieruje to naszą uwagę na własność systemu, jaką jest zdolność tworzenia sprzężeń. W tym przypadku, są to sprzężenia występujące pomiędzy podsystemami systemu - „las”.

Inną, ważną funkcją, jaka ujawnia się w systemowym ujęciu lasu jest - sterowanie. Może ono przybierać, na przykład, formę oddziaływania na otoczenie w celu wprowadzenia w nim zmian (korzystnych z punktu widzenia funkcjonujących $w$ nim systemów). Sterowanie może być związane z wywoływaniem zmian w innym systemie (Mazur 1976: 107; Kempisty: 420). Zgodnie z narracją prowadzoną w tym duchu - drzewa tworzą mikroklimat sprzyjający rozwojowi dorosłych i młodocianych osobników, dbają o potomstwo (młode siewki) i opiekują się nim. Przykładem mogą być rozdziały: Leśna szkoła czy Urząd opieki społecznej, w którym opisane są sytuacje, gdy drzewa, doznawszy uszkodzenia jakiejś funkcji, otaczane są opieką przez sąsiednie drzewa. Znajdziemy tam taki opis: „[d]rzewo pozbawione kory nie może odprowadzić cukrów z liści do korzeni. Korzenie umierają więc z głodu, przestają pełnić funkcję pomp, a gdy woda przestaje docierać poprzez drewno pnia do korony, całe drzewo usycha. Jednak wiele okazów dzielnie rosło nadal z mniejszym lub większym sukcesem. Dzisiaj wiem, że było to 
możliwe tylko dzięki pomocy całych i zdrowych sąsiadów. Przejęli oni przerwaną działalność aprowizacyjną korzeni za pomocą własnej podziemnej sieci i tym sposobem umożliwili przetrwanie kompanów. Niektórym nawet się udało pokryć ubytki w korze nową tkanką [n]auczyło mnie to, jak potężna może być społeczność drzew. Łańcuch jest tak silny, jak jego najsłabsze ogniwo - autorami tego starego porzekadła spokojnie mogłyby być drzewa. A ponieważ intuicyjnie to wiedzą, bezwarunkowo sobie pomagają." (Wohlleben 2016: 28). Innym przykładem wpływu jednych drzew na drugie (sterowania) może być opieka rodzicielska. „Środkiem wychowawczym jest przykręcenie światła. Ale czemu służy to ograniczenie? Czyżby rodzice nie chcieli, by ich potomstwo jak najszybciej się usamodzielniło? Najwyraźniej drzewa mają w tej sprawie inne poglądy, a niedawno uzyskały jeszcze wsparcie ze strony nauki. Stwierdziła ona, że powolny wzrost $\mathrm{w}$ młodości jest warunkiem osiągnięcia podeszłego wieku. [O]dpowiednie wychowanie jest gwarantem długiego życia, jednakże czasem cierpliwość drzewnych dzieci jest wystawiana na ciężką próbę. [U]mila im się zresztą czas oczekiwania. Rodzice nawiązują z nimi kontakt poprzez korzenie i przekazują cukry oraz inne składniki pokarmowe. Można by powiedzieć - karmią własną piersią drzewne oseski." (Wohlleben 2016: 43)

Systemowe ujęcie lasu pozwala stwierdzić, że podsystemy systemu las sterują się we własnym interesie (np. jak w przypadku systemu autonomicznego w ujęciu Mariana Mazura). Prowadzą działania mające na celu zapobieżenie utracie zdolności utrzymywania się w stanie równowagi funkcjonalnej (por. Mazur 1966: 57). Przeciwdziałają zaburzeniu struktury, utracie własności czy funkcji podsystemów, ale również nadsystemu jakim jest las. Wohlleben opisuje ten mechanizm wręcz dramatycznie: „[t]am, pod drzewami, rządzi prawo silniejszego. Każdy gatunek chciałby przeżyć i zabiera innemu to, czego sam potrzebuje. Zasadniczo nikt nie zna litości, a system przed gigantycznym załamaniem chronią jedynie mechanizmy obronne, które przeciwdziałają bezprawnej ingerencji. Ostatnie zabezpieczenie stanowi własny interes genetyczny - ten, kto jest zbyt chciwy i zbyt wiele zabiera dla siebie, nic w zamian nie dając, pozbawia się własnej bazy życiowej i ginie. Z tego powodu większość gatunków wykształciła zachowania wrodzone, chroniące las przed gospodarką rabunkową" . (Wohlleben 2016: 119)

Powyższe wiąże się z kolejnymi własnościami systemów, jakimi są adaptacja i homeostaza. Wiele przykładów prezentowanych przez Wohlleben'a, dotyczy funkcjonowania systemów leśnych. Autor często zaznacza, że konsekwencją prezentowanych mechanizmów jest stabilne funkcjonowanie czy utrzymanie homeostazy. Wzajemne sprzężenia systemów leśnych, oddziaływania przybierają postać różnego rodzaju „współpracy", której wynikiem może być adaptacja do zmieniającej się charakterystyki otoczenia. Przykładem takiej sytuacji może być następujący fragment, w którym Wohlleben zastanawia się: „Dlaczego jednak drzewa są do tego stopnia istotami społecznymi, dlaczego dzielą się pokarmem z krewniakami $\mathrm{z}$ tego samego gatunku, a przez to tuczą konkurencję? Powody są identyczne z tymi, którymi kierują się ludzkie społeczności razem łatwiej sobie radzić. Drzewo nie jest lasem, samo nie wytworzy lokalnego, zrównoważonego klimatu, jest bez reszty wydane na pastwę wiatru i pogody. Natomiast wiele drzew tworzy wspólnie ekosystem, który łagodzi skutki skrajnych upałów i mrozów, gromadzi dużą ilość wody i produkuje bardzo wilgotne powietrze. W takim środowisku drzewa mogą rosnąć bezpiecznie i dożywać matuzalemowego wieku. By to osiągnąć, społeczność musi za wszelką cenę trzymać się razem. Gdyby wszystkie okazy troszczyły się tylko o siebie, wówczas niejeden nie doczekałby starości. Skutkiem bezustannych zgonów byłoby mnóstwo dużych dziur w sklepieniu drzewostanu, przez

2 Nie chodzi tu o gospodarkę rabunkową prowadzoną przez człowieka. 
co burze łatwiej dostawałyby się do środka i obalały kolejne drzewa. Letni upał przenikałby aż do leśnej gleby i wysuszał ją. Wszyscy by cierpieli." (Wohlleben 2016: 13-14).

W ten sposób, naszkicowany został obraz lasu w ujęciu systemowym. W obrazie tym, możliwe są do zidentyfikowania zarówno struktura systemu (systemu wielkiego wraz z jego podsystemami), jak i zasadnicze funkcje i własności systemów. W obrazie tym można iść nieco dalej szlakiem wytyczonym przez ujęcie systemowe, dostrzegając specyfikę systemu autonomicznego wraz z jego cechami charakterystycznymi (wspomniana równowaga funkcjonalna czy działanie „we własnym interesie" - zapobieganie utracie sterowania itp.). Wszystkie konsekwencje wynikające, z tak zarysowanego, systemowego ujęcia lasu przekładają się na „działania lasu" na rzecz dobrostanu człowieka („zdrowe powietrze”, źródło „darów lasu” itp.); ochrony klimatu; gospodarki wodnej itp. (Wohlleben 2016: 100-118). Tym samym, mogą stanowić punkt wyjścia do dalszych analiz związanych z relacją pomiędzy człowiekiem a systemem leśnym. Zagadnienie to mogłoby stanowić podstawę odrębnego, szerszego opracowania.

W tym miejscu należy zwrócić szczególną uwagę, na charakterystykę prezentowanego sposobu ujmowania i opisu podejmowanych zagadnień. Autor książki Sekretne życie drzew, nie poprzestaje wyłącznie na ścisłym trzymaniu się perspektywy systemowej. Charakterystyczne jest rozszerzanie analogii przez autora - obecne także w przytaczanych już fragmentach. Bardziej dobitnie ukazuje to niniejszy cytat: „[k]orzystanie z drewna jest w porządku, o ile drzewa mogły żyć w zgodzie z wymogami i potrzebami swego gatunku. A to oznacza, że mają prawo do zaspokojenia swych potrzeb społecznych, że mają prawo rosnąć w prawdziwym leśnym klimacie i na nietkniętych glebach oraz przekazać swą wiedzę następnym pokoleniom. Przynajmniej część z nich powinna mieć prawo godnie się zestarzeć, a wreszcie umrzeć naturalną śmiercią. Tym, czym w produkcji żywności są uprawy ekologiczne, tym dla lasu gospodarka przerębowa. Zgodnie z jej zasadami drzewa w każdym wieku i we wszystkich fazach wzrostu są ze sobą przemieszane, tak że drzewne dzieci wzrastają u stóp swych rodziców." (Wohlleben 2016: 244).

Zaprezentowane fragmenty jako przykłady pewnego typu podejścia do zagadnień prezentowanych w ujęciu systemowym, inspirują do zwrócenia uwagi na walory takiego ujęcia, mogą także wskazywać na pewne jego mankamenty. Dyskusyjne jest to, czy mankamenty te wynikają z samej "natury” ujęcia systemowego, czy może z nieuzasadnionych wobec niego oczekiwań, niewłaściwego zastosowania czy nieuzasadnionego poszerzania jego zastosowania, wyciągania nieuzasadnionych wniosków itp. Przykładem może być tu proces przechodzenia od ujęcia systemowego do personifikacji różnych „szczególnych przypadków” systemów. Zmierza się w nim następnie do formułowania postulatu przyznawania wybranym, szczególnym przypadkom systemów (drzewom, urządzeniom, aplikacjom komputerowym itp.) nie tylko atrybutów czy cech przynależnych człowiekowi, ale także określonych praw. Przykład takiego procesu stanowią fragmenty cytowanej książki.

Jest to ważny moment, w którym należy podjąć próbę określenia mocnych i słabych stron ujęcia systemowego. Jest to o tyle istotne, że „słabe strony” mogą przekładać się na powstanie zaburzonego obrazu prezentowanego układu, a w konsekwencji powodować dezorientację wobec prezentowanego obszaru problemowego. W przypadku systemu, jakim jest las, dezorientacja może przekładać się na negatywne działania prowadzone przez człowieka $w$ ramach korzystania z systemu leśnego. Świadomość praktycznych konsekwencji dotyczących tak wrażliwych i cennych systemów jakimi są lasy wzmacnia jeszcze rangę prowadzonych analiz. 


\section{Mocne i słabe strony ujęcia systemowego}

Prezentowane mocne i słabe strony zostały wybrane arbitralnie jako zdaniem autora, najbardziej charakterystyczne i adekwatne do podejmowanych zagadnień. Obszar z nimi związany zawężony został do kwestii zasygnalizowanych w pierwszej części niniejszego artykułu. Dokonanie takiej analizy wobec ujęcia systemowego w zaproponowanym obszarze - pozwala na określenie możliwości, wynikających z mocnych i ograniczeń płynących ze słabych stron takiego ujęcia.

\subsection{Mocne strony ujęcia systemowego}

Wskazując na „mocne strony” ujęcia systemowego, należy przede wszystkim docenić możliwość opisu i wyjaśniania, często skomplikowanych zjawisk mechanizmów, relacji, oddziaływań itp. (Mazur 1976: 5-62) Może być to podstawą do edukacyjnego wykorzystania takiego ujęcia. Jest ono $\mathrm{z}$ powodzeniem używane w literaturze popularyzującej zagadnienia związane $\mathrm{z}$ funkcjonowaniem środowiska (jak ma to miejsce w książce Sekretne życie drzew).

Dzięki perspektywie systemowej, zyskuje się możliwość określenia charakteru działań człowieka wobec jego otoczenia (środowiska) oraz celów tych działań. Odpowiednio określone cele będą następnie rzutowały na sposoby prowadzenia tych działań. W przypadku relacji człowiek - las, możliwe jest określenie charakteru działań człowieka względem lasu jako działań zmierzających do utrzymania, zachowania lub przywracania struktury, własności i funkcji wchodzących w grę systemów (wytyczne o charakterze ogólnym). Cele (wytyczne) szczegółowe, mogą być formułowane w odniesieniu do konkretnych (określonych, wybranych w zależności od potrzeb czy kontekstu) własności lub funkcji systemów. W takim kluczu prezentowane były powyżej cytaty z książki Sekretne życie drzew.

Perspektywa systemowa pozwala na odniesienia do konkretnego wzorca systemowego np. systemu autonomicznego (Por.
Mazur 1966), czy systemu względnie izolowanego (Ingarden 2003), a co za tym idzie wskazania określonej struktury, elementów systemu, oraz występujących pomiędzy nimi relacji (sprzężeń, oddziaływań itp.). Dopuszcza się wówczas wskazywanie „szczególnych przypadków" takich systemów i prowadzenie analiz w odniesieniu do ich struktury, własności i funkcji. Następnie, przez analogię, orzekanie o owych „szczególnych przypadkach”. W przytoczonych wcześniej przykładach była o tym mowa przy okazji wskazania na sterowanie się lasu „we własnym interesie".

Ujęcie systemowe, poprzez sterowanie, może być uwzględnione w zarządzaniu, a w szczególności w procesie decyzyjnym. Wobec tego, ujęcie systemowe, oprócz określenia relacji pomiędzy systemem a otoczeniem (środowiskiem), umożliwia wypracowanie określonych metodyk postępowania/działania w ramach tych relacji. Przykładem tak spożytkowanego ujęcia systemowego może być konstruowanie procesu decyzyjnego ufundowanego na systemie sterującym (np. w propozycji Mazura) (Embros 2016). Inny przykład może stanowić metodyka PDCA (tzw. Cykl Deminga) stosowana w ramach systemów zarządzania środowiskowego, implementowanych w przedsiębiorstwach (por. Matuszak-Flejszman 2007; PN-EN ISO 14001:2015). W takiej sytuacji, możliwe staje się wskazanie miejsca, w strukturze systemu (decyzyjnego), właściwego dla elementów kontekstu. Mogą to być zarówno kwestie przyrodnicze, techniczne itp., jak i estetyczne, aksjologiczne czy etyczne itp. (Dzwonkowska 2016)

Zastosowanie ujęcia systemowego do problematyki związanej z rozwiązywaniem problemów decyzyjnych, umożliwia podjęcie pełniejszej analizy szeroko rozumianego procesu decyzyjnego. Dzięki temu, możliwe jest wskazanie jego konstytutywnych cech, komponentów, własności oraz obszarów ewentualnych niesprawności funkcjonowania tego systemu. W przypadku, interesujących nas relacji i wzajemnych oddziaływań, pomiędzy człowiekiem (który może być tu 
traktowany jako szczególny przypadek systemu autonomicznego), a lasem (systemem wielkim wraz z jego podsystemami) - ma to niebagatelne znaczenie. Możliwe jest bowiem wykorzystanie analiz systemowych zarówno do celów diagnostycznych czy prognostycznych, jak i do wykrywania źródeł niesprawności procesu decyzyjnego oraz ustalania wpływu wykrytych nieprawidłowości na konkretne działania człowieka względem lasu.

Ujęcie systemowe umożliwia przyjęcie perspektywy procesowej. Ukazuje ona dynamiczne przebiegi zjawisk, relacji, sprzężeń itp. w czasie. Tym samym kieruje uwagę nie tylko na sam przebieg czy charakterystykę procesu, ale także na zasięg czy stopień oddziaływania systemów. Perspektywa taka staje się szczególnie istotna przy rozpatrywaniu zasięgu i stopnia oddziaływania człowieka na system leśny. Ujawnia się przy tym cały obszar problemowy związany z potrzebą określania granic takiego oddziaływania (Latawiec 2016). Korzystając z metod systemowych możliwe jest podjęcie podobnych zagadnień np. na etapie optymalizacji (wspomniany wyżej wzorzec procesu decyzyjnego bazującego na systemie sterującym M. Mazura) a w szczególności procedur związanych z analizą ryzyka itp.

Wskazane mocne strony ujęcia systemowego ujawniają znaczny potencjał tak formułowanej perspektywy. Należy, w tym miejscu zaznaczyć, że ów potencjał pozwala na pozostanie na gruncie ujęcia systemowego. Tym samym nie ma konieczności „poszerzania interpretacji” czy stosowania dalszych zabiegów o charakterze literackim, aby właściwie i adekwatnie pożytkować ujęcie systemowe.

\subsection{Słabe strony ujęcia systemowego}

W odniesieniu do wskazanych, wśród mocnych stron, walorów związanych z opisem skomplikowanych zjawisk i/lub procesów czy relacji - należy zaznaczyć, że ujęcie systemowe, chociaż „sprawdza się" w opisie, to nie wyczerpuje w pełni funkcji wyjaśniającej. Jest pewnym przybliżeniem, a wobec tego - może nie uwzględnić w pełni bogactwa, różnorodności i złożoności systemu oraz wszystkich wchodzących w grę zjawisk. W pewnych przypadkach może być uznane za niewystarczające (np. w przypadku systemów społecznych por. (Crozier i Friedberg 1982: 212-225). Odnosząc się do naszego przykładu - może nie uchwycić, niekiedy istotnych obszarów np. „pozamaterialnych elementów kontekstu” - tego, co, poprzez bezpośredni kontakt (np. z komponentami lasu i z lasem jako całością), poprzez uczestnictwo w spotkaniu z całą realnością lasu „uwzniośla” człowieka i poszerza jego kontakt z tym, co transcenduje przyrodniczą realność lasu (mistyczne gaje, „magiczne” polany itp.).

Należy również podkreślić, że ujęcie systemowe nie zastępuje metod redukcyjnych. może stanowić ich uzupełnienie. Jak pisał Ervin Laszlo w książce Systemowy obraz świata: „Tradycyjny redukcjonizm dopatrywał się wspólnoty, kryjącej się pod różnorodnością, we wspólnie dzielonej substancji, w rodzaju materialnych atomów, natomiast współczesna ogólna teoria systemów cech wspólnych doszukuje się we wspólnie dzielonych aspektach organizacji. Podejście redukcjonistyczne porównać można do traktowania stodoły, domu mieszkalnego i biurowca jako po prostu wielu budowli, wzniesionych z cegły i cementu, przy czym pomija się różnicujące te obiekty właściwości indywidualne. Teoria systemowa ujmuje je natomiast $w$ kategoriach organizacji materiału, nadającej każdej z tych budowli swoiste cechy. Odkrywa powtarzające się wzorce organizacji, takie jak podłogi, drzwi i okna, charakteryzując je jako różne wariacje na ten sam temat. W teorii systemowej nie utrzymuje się jednak, że stodołę, dom i biurowiec zredukować można do tego samego, rozbierając je na poszczególne cegły i grudki cementu. Redukcja taka wyeliminowałaby to właśnie, co w każdej ze wspomnianych budowli jest istotne: organizację materiału wedle różnorodnie funkcjonujących modułów." (Laszlo 1978: 41). Problematyka ta znajduje rozwinięcie w postulacie Gregory'ego 
Bateson'a mówiącego o tym, że „dwa opisy są lepsze niż jeden" i koncepcji abdukcji (Por. Bateson 1996: 97-193).

$\mathrm{Na}$ mankamenty ujęć systemowych wskazuje się, gdy, w odniesieniu do ujęcia systemowego, rozszerzane są analogie i interpretacje (por. przypis ze strony $225 \mathrm{w}$ : Crozier i Friedberg 1982). Taki proces może niekiedy prowadzić wręcz do personifikacji, w odniesieniu do szczególnych przypadków rozpatrywanych systemów (lasu, drzew, zwierząt itp.). Jak było to wskazane na przykładzie książki Sekretne życie drzew, taki sposób traktowania ujęcia systemowego, może prowadzić następnie do porównywania drzewa z człowiekiem a lasu ze społecznością ludzką. Poszerzanie analogii może skutkować niekiedy rozumowaniem polegającym na tym, że - skoro drzewo jako system, ma takie same własności i funkcje jak człowiek (postrzegany jako system), to możliwe jest ich porównywanie a nawet zrównywanie czy redukcja do któregoś z systemów. Do którego z nich, jest kwestią arbitralnej decyzji. Nie koniec jednak na tym. Niekiedy, jak było to $\mathrm{w}$ prezentowanych przykładach, na takiej podstawie konstruowane mogą być określone postulaty. Jeśli arbitralna decyzja będzie odpowiednio odważna to, postulaty mogą dotyczyć np. przyznawania tych samych praw, które przysługują człowiekowi drzewom. Lub szerzej - postulat przyznania praw przysługujących społeczności ludzkiej - społeczności drzew, innych roślin czy zwierząt.

Powyższe może budzić negatywne konotacje, związane z ujęciem systemowym jako prowadzącym do trywializowania podejmowanej problematyki np. poprzez utożsamianie właściwości komponentów przyrodniczych z właściwościami przysługującymi człowiekowi. Na tej podstawie, negatywnie będzie oceniane ujęcie systemowe jako prowadzące do fałszowania obrazu analizowanych zjawisk, obiektów czy wreszcie obrazu świata. Na negatywną ocenę wpłynie także, pojawiająca się niekiedy na skutek daleko idących analogii czy interpretacji, nie mająca swojego pokrycia w faktach (świecie realnym) - swego rodzaju życzeniowość czy wręcz „wirtualizacja” rozważanych systemów. W naszym przykładzie, może to być obraz lasu, który nie pokrywa się z rzeczywistością. Innym przykładem może być - znane z odniesień do koncepcji Gai wręcz, ubóstwienie konstruktu myślowego (o nazwie Gaia) ufundowanego na ujęciu systemowym.

\section{Podsumowanie}

Analiza mocnych i słabych stron ujęcia systemowego ujawnia obszary problemowe, wiążące się z określonymi wątpliwościami. Zasadniczy wątek dotyczy tego czy, bazując na ujęciu systemowym wskazane i zasadne jest „poszerzanie” interpretacji czy analogii - aż do personifikacji (np. roślin i/ lub zwierząt - charakterystycznej dla wielu opracowań popularyzujących świat przyrody)? Otwarte zostaje pytanie - na podstawie jakiego mechanizmu, zasady, metodyki czy metodologii jest to możliwe? Wiąże się to dalej z wątpliwością - Czy z „rozszerzonej analogii” wynikają jakieś merytorycznie uzasadnione przesłanki do dalszych rozstrzygnięć. Innymi słowy, czy dostępna jest ścieżka argumentacji, pozwalająca na wyprowadzenie, z daleko posuniętej analogii, merytorycznie uzasadnionych konsekwencji. Np. czy z personifikacji drzewa można wyprowadzić argumentację na rzecz przyznania mu praw analogicznych do tych, które przysługują człowiekowi (osobie)?

Odnosząc się do słabych stron związanych $\mathrm{z}$ ujęciem systemowym należy stwierdzić, że ujęcie systemowe (jako takie) nie prowadzi do personifikacji (drzew, innych roślin, zwierząt, jakiegoś ekosystemu czy planety). Fakt, że posiadają te same własności i funkcje (rozpatrywane jako systemy) nie prowadzi do ich utożsamiania lub sprowadzania jednych do drugich. Trzeba podkreślić, że „poszerzanie interpretacji” jest, dopuszczalnym i często uzasadnionym względami lepszego przekazu (skomplikowanych treści) zabiegiem literackim, jednak nie wydaje się wynikać wprost $\mathrm{z}$ analiz systemowych. Innymi słowy - mamy tu do czynienia z wnioskami, 
jakie mogą być wyciągane w odniesieniu do określonych zabiegów literackich (np. personifikacji systemów leśnych czy drzew) lub w ramach ujęcia systemowego. Jak się wydaje oba przypadki mieszane są w nurcie ujęcia systemowego.

Odnosząc się do mocnych stron ujęcia systemowego należy podkreślić, że w jego ramach można wskazywać: relacje system otoczenie, odniesienia do struktury systemów, do ich własności czy funkcji, a także do hierarchii systemowej (Bertalanffy 1984; Sadowski 1978; Gomółka 1994). Z ujęcia systemowego można wyprowadzić, w zasadny sposób, zarówno określenie charakteru działań (celów ogólnych działań) człowieka wobec jego otoczenia (środowiska), jak i określić cele tych działań. Tak określone cele będą następnie wyznaczały sposoby prowadzenia tych działań. Zasadne jest następnie podejmowanie prób określenia ich ram i granic (Latawiec 2016). W stosunku do przypadku, który nas interesuje: relacja człowiek - las możliwe jest, w kluczu systemowym, określenie charakteru działań człowieka względem lasu, jako działań zmierzających do utrzymania, zachowania lub przywracania struktury, własności i funkcji wchodzących w grę systemów (wytyczna o charakterze ogólnym). Cele szczegółowe będą zależne od poszczególnych własności czy funkcji systemów.

Wobec powyższego, nie wydaje się być konieczne stosowanie zabiegów literackich w celu odpowiedniego spożytkowania ujęcia systemowego. W ramach samego ujęcia systemowego można opisywać i opracowywać różne mechanizmy występujące w złożonych układach. Dzięki optymalizacji (umieszczonej w ramach systemu sterującego), można umieszczać kwestie, które dotąd nie znajdowały właściwego sobie miejsca w interesującym nas obszarze problemowym. Wydaje się, że wnioski, do jakich dochodzić się będzie na tej drodze, będą wówczas uzasadnione metodologicznie w ramach ujęcia systemowego. Innymi słowy - bez dodatkowych zabiegów literackich (typu „poszerzanie interpretacji” czy personifikacja szczególnych przypadków jakichś systemów w odniesieniu do ich własności czy funkcji w świetle ujęcia systemowego), wychodzących poza ujęcie systemowe.

Charakterystyczna, szeroka perspektywa ujęcia systemowego - pozwala na uwzględnianie kontekstu, w jakim przebiega proces decyzyjny poprzedzający działanie człowieka. W ramach kontekstu możliwe jest zaś uwzględnienie zarówno obszaru przyrodniczego czy technicznego, jak i kwestii aksjologicznych, etycznych itp. (Dzwonkowska 2016). Możliwe jest uwzględnienie zagadnienia dotyczącego określenia profilu sprawcy czynu (atrybuty przysługujące człowiekowi). W tym kontekście, ujęcie systemowe, nie tyle wprowadza zagadnienia tego typu, czy pozwala rozstrzygać w kwestiach ujawniających się w ramach tych obszarów problemowych, ile umożliwia określenie miejsca właściwego tym zagadnieniom (istotnym z punktu widzenia określonego kontekstu).

Ujęcie systemowe otwiera przestrzeń i wskazuje miejsce (z możliwością uzasadnienia) dla zagadnień przekraczających perspektywę stricte systemową. W odniesieniu do naszego przykładu relacji człowiek - las: w ramach ujęcia systemowego mieści się możliwość rozważania sytuacji, w której człowiek szuka i odnajduje w lesie, poza runem czy drewnem na opał lub budowę jeszcze inne dobra zgodne $\mathrm{z}$ jego potrzebami (duchowe, estetyczne itp.) - por. genius loci Dubosa czy oikofilia Scrutona (Dubos 1986; Scruton 2017, s. 31). Należy jeszcze raz podkreślić to, co wypływa z powyższego - nie ma konieczności poszukiwania w podsystemach systemu las czy też w samym tym systemie rozszerzonych analogii prowadzących do ich personifikacji (humanizacji) aby następnie, na tej podstawie, udzielać im praw przysługujących człowiekowi. Wydaje się to metodologicznie nieuzasadnione w ramach ujęcia systemowego.

Na gruncie ujęcia systemowego (bez konieczności odwoływania się do dodatkowych zabiegów „(nad)interpretacyjnych”) możliwe jest ukazanie, że deforestacja czy inne formy dewastacji lasu (zaburzenie relacji 
człowiek - las), są dla człowieka, czymś więcej niż tylko pozbawieniem go „czystego powietrza” czy innych pożytków materialnych. Możliwe jest ujawnienie, że w tym kontekście pozbawia się go możliwości dostępu do dóbr czy wartości przekraczających wspomniane zasoby materialne. Odbierana jest mu radość wypływająca ze spotkania z "naturą" (przyroda lasu) i "transcendencją" (Życiński 1992). Nie zastąpią tego żadne artefakty techniczne (również systemy), wciągające raczej człowieka w świat wirtualny (Latawiec 2008), który nie jest w stanie zaspokoić tych tęsknot i autentycznych potrzeb człowieka, które może on zaspakajać wchodząc w relację z systemem leśnym.

\section{Bibliografia}

Bateson G., 1996, Umyst i przyroda. Jedność konieczna, PIW, Warszawa.

Bertalanffy L., 1984, Ogólna teoria systemów. Podstawy, rozwój, zastosowania, PWN, Warszawa.

Crozier M., Friedberg E., 1982, Człowiek $i$ system. Ograniczenia działania zespołowego, Państwowe Wydawnictwo Ekonomiczne, Warszawa.

Dubos R., 1986, Pochwata różnorodności, PIW, Warszawa.

Dzwonkowska D., 2016, Zagadnienie cnót mniejszych $w$ etyce środowiskowej, w: Studia Ecologiae et Bioethicae 14/2016 (1), 35-53.

Embros G., 2016, Prakseologiczne uwarunkowania procesu decyzyjnego w ochronie środowiska, w: Studia Ecologiae et Bioethicae 14/2016 (1), 101-127.

Gomółka Z., 1994, Elementy ogólnej teorii systemów, Wydaw. Naukowe Uniwersytetu Szczecińskiego (Rozprawy i studia, T. (CCXXXIII) 159), Szczecin. Ingarden R., 2003, O odpowiedzialności i jej podstawach ontycznych, w: Książeczka o człowieku, Wydawnictwo Literackie, Kraków, 71-169.

Kempisty M., 1973, Sterowanie, w: Kempisty M. (red.), Mały słownik cybernetyczny, Wiedza Powszechna, Warszawa, 420.
Laszlo E., 1978, Systemowy obraz świata, PIW, Warszawa.

Latawiec A., 2008, Użyteczność systemowego ujęcia świata wirtualnego, w: W kierunku filozofii klasycznej. Inspiracje i kontynuacje. Księga jubileuszowa ofiarowana Profesorowi Edwardowi Nieznańskiemu, red. Jan Krokos, Kordula Świętorzecka i Roman Tomanek. Wydaw. UKSW, Warszawa, 303-312.

Latawiec M., 2016, Rozpoznawanie granic ingerencji człowieka w środowisko przyrodnicze, w: Studia Ecologiae et Bioethicae 14/2016 (1), 77-97.

Lubański M., 1992, Informacja - System, w: Zagadnienia filozoficzne współczesnej nauki, red. Michał Heller, Mieczysław Lubański i Szczepan Ślaga. Warszawa: Wydaw. ATK, s. 13-153.

Matuszak-Flejszman A., 2007, System zarzadzania środowiskowego w organizacji, Wyd. Akademii Ekonomicznej, Poznań.

Mazur M., 1966, Cybernetyczna teoria układów samodzielnych, PWN, Warszawa.

Mazur M., 1976, Cybernetyka i charakter, PIW, Warszawa.

Mynarski S., 1979, Elementy teorii systemów i cybernetyki, PWN, Warszawa.

PN-EN ISO 14001, 2015, Systemy Zarzadzania Środowiskowego-wymagania i wytyczne stosowania, Warszawa.

Sadowski W., 1978, Podstawy ogólnej teorii systemów. Analiza logiczno-metodologiczna, PWN, Warszawa.

Scruton R., 2017, Zielona filozofia. Jak poważnie myśleć o naszej planecie, Zysk i S-ka. Poznań.

Weinberg G. M., 1979, Myślenie systemowe, Wyd. Naukowo- Techniczne Warszawa.

Wohlleben P., 2016, Sekretne życie drzew, Otwarte, Kraków.

Życiński J., 1992, Ułaskawienie natury, Znak, Kraków. 


\title{
Forest in systemic perspective: Weaknesses and strengths
}

\begin{abstract}
In this paper, some exemplary methods of describing both a 'forest' system and its subsystems are presented. In order to precisely offer the manner of constructing a systemic image of the forest and its subsystems, all issues related to the systemic approach are clarified. The weaknesses and strengths of such an approach were juxtaposed and revealed the possibilities of using them to shape the man-forest relationship. Attention was paid to the 'expanding of interpretation' of the systemic approach and the subsequent consequences. The above, together with the after-effects, remains the focal point and main goal of the paper. Such a described systemic perspective may be used, for example, in environmental education. It can support a depiction or explanation of mechanisms and phenomena occurring within the forest system. In addition, it may be the basis for working out some 'system instruments' subsequently used in shaping attitudes and actions towards the forest and translating into the manforest relationship. This can be reflected in decision-making process, broadly understood, preceding the actions taken in the field of forest system management.
\end{abstract}

\section{Keywords}

forest, systemic perspective, anthropomorphisation, interpretation 